\title{
PENGARUH KEPEMIMPINAN DEMOKRATIS DAN MOTIVASI KERJA TERHADAP KINERJA DOSEN STAI IBNU SINA BATAM KEPULAUAN RIAU
}

\author{
Rosnawati $^{* 1}$, Lias Hasibuan ${ }^{2}$, Kasful Anwar Us ${ }^{3}$ \\ ${ }^{1,}$ Sekolah Tinggi Agama Islam Ibnu Sina Batam Kepulauan Riau \\ ${ }^{2,3}$ Program Pascasarjana UIN Sultan Thaha Syaifuddin Jambi \\ e-mail: ${ }^{1}$ zahra_algiffari66@yahoo.com, ${ }^{2}$ Lhas10@yahoo.co.id, ${ }^{3}$ kasfulanwarus@gmail.com
}

\begin{abstract}
Abstrak
Penelitian ini bertujuan untuk menganalisis: Pengaruh Kepemimpinan Demokratis dan Motivasi Kerja Terhadap Kinerja Dosen STAI Ibnu Sina Batam Kepulauan Riau. Pendekatan penelitian ini menggunakan penelitian survey. Waktu penelitian dilakukan mulai bulan Maret 2021. Populasi penelitian adalah dosen yang mengajar di STAI Ibnu Sina Batam Kepulauan Riau sebanyak 31 orang. Pemilihan sampel dalam penelitian ini dilakukan dengan menggunakan metode sensus dimana populasi bertindak sebagai sampel. Hasil penelitian menunjukkan bahwa : 1) Terdapat pengaruh positif dan signifikan kepemimpinan demokratis secara sendiri-sendiri (parsial) terhadap kinerja dosen pada STAI Ibnu Sina Batam Kepulauan Riau, dengan $\mathrm{t}_{\text {hitung }}=$ $\left.3,936>t_{\text {tabel }}=1,99.2\right)$ Tidak terdapat pengaruh positif dan signifikan motivasi kerja secara sendiri-sendiri (parsial) terhadap kinerja dosen pada STAI Ibnu Sina Batam Kepulauan Riau, dengan $\left.\mathrm{t}_{\text {hitung }}=0,195<\mathrm{t}_{\text {tabel }}=1,99.3\right)$ Terdapat pengaruh secara bersama-sama (simultan) kepemimpinan demokratis dan motivasi kerja terhadap kinerja dosen pada STAI Ibnu Sina Batam Kepulauan Riau, dimana $\mathrm{F}_{\text {hitung }}=12,841>\mathrm{F}_{\text {tabel }}=2,73$. Berdasarkan hasil penelitian diperoleh koefisien determinasi $\left(\mathrm{R}^{2}\right)$ sebesar 0,478 atau $(47,8 \%)$. Hal ini menunjukkan bahwa 47,8\% kinerja dosen dipengaruhi oleh kepemimpinan demokratis dan motivasi kerja. Sedangkan $52,2 \%$ dipengaruhi oleh variabel lain yang tidak dimasukkan dalam model penelitian ini.
\end{abstract}

Kata kunci : kepemimpinan demokratis, motivasi kerja dan kinerja dosen

\section{Abstract}

This study aims to determine and analyze: The Effect of Democratic Leadership and Work Motivation on Lecturer Performance at STAI Ibnu Sina Batam, Riau Islands. This research approach uses survey research. The time of the research was carried out starting in March 2021. The research population was 31 lecturers who taught at STAI Ibnu Sina Batam, Riau Islands. The sample selection in this study was carried out using the census method where the population acted as a sample. The results show that: 1) There is a positive and significant influence of democratic leadership individually (partial) on the performance of lecturers at STAI Ibnu Sina Batam, Riau Islands, with tcount $=3.936>$ ttable $=1.99$. 2) There is no positive and significant effect of work motivation individually (partial) on the performance of lecturers at STAI Ibnu Sina Batam, Riau Islands, with tcount $=0.195<$ ttable $=1.99 .3)$ There is a simultaneous (simultaneous) influence of democratic leadership and work motivation on the performance of lecturers at STAI Ibnu Sina Batam, Riau Islands, where Fcount $=12.841$ > Ftable $=2.73$. Based on the results of the study, the coefficient of determination $\left(R^{2}\right)$ was 0.478 or $(47.8 \%)$. This shows that $47.8 \%$ of lecturers' performance is influenced by democratic leadership and work motivation. While $52.2 \%$ is influenced by other variables that are not included in this research model.

Keywords: democratic leadership, work motivation and lecturer performance

\section{PENDAHULUAN}

Pendidikan adalah proses perkembangan pribadi dan sosial yang sangat menentukan. Kemajuan masyarakat dapat dilihat dari perkembangan masyarakat. Dengan terus berkembangnya era globalisasi dan modernitas saat ini, peningkatan 
kualitas pendidikan seakan menjadi isu yang mendesak. Dalam pengelolaan organisasi pendidikan, perlu adanya arah peningkatan mutu pendidikan. Pendidikan yang berkualitas merupakan pondasi untuk perkembangan lebih lanjut. Oleh karena itu, menurut Zazin (2011:5) pengelola pendidikan harus mampu menyesuaikan programprogram yang akan direncanakan dengan aturan-aturan atau kebijakan pemerintah serta kebutuhan public guna meningkatkan kualitas melalui kreativitas, inovasi yang tinggi dan strategi yang baik dalam konteks sistem (mengoptimalkan seluruh elemen), manajemen, termasuk proses input dan output.

Kepemimpinan merupakan salah satu elemen penting yang mesti menjadi perhatian dalam pengelolaan suatu organisasi atau lembaga pendidikan disertai kualifikasi sumber daya manusia dalam menjalankan fungsi manajemen demi terwujudnya tujuan organisasi. Eksistensi seorang pemimpin yang memiliki jiwa kepemimpinan sangatlah diperlukan. Karena keberadaan pemimpin yang berkualitas, jujur dan amanah dapat mewujudkan stabilitas keamanan suatu bangsa. Dalam bidang organisasi pun demikian, dimana baik buruknya sebuah organisasi sangat tergantung kepada faktor kepemimpinan. Seorang pemimpin yang demokratis akan selalu memberikan kesempatan kepada bawahannya untuk menyampaikan pendapat dengan tetap memposisikan dirinya sebagai seseorang yang akan mengendalikan, mengawasi, mengelola dan mengatur sebuah organisasi atau lembaga pendidikan serta memastikan bahwa bawahannya telah melaksanakan tugas dan tanggung jawab dengan sebaikbaiknya sesuai tujuan yang telah ditetapkan bersama. Kondisi tersebut juga berlaku di lingkungan perguruan tinggi, bahwa seorang rektor dapat menerapkan gaya kepemimpinan demokratis dalam menjalankan dan mengelola perguruan tinggi dalam rangka pencapaian visi, misi dan tujuan perguruan tinggi.

Type atau gaya kepemimpinan demokratis sebagaimana yang dijelaskan oleh Thoha (2013:49) mengatakan bahwa gaya kepemimpinan merupakan norma perilaku yang digunakan oleh seseorang pada saat orang tersebut mencoba mempengaruhi perilaku orang lain seperti yang ia lihat. Sejalan dengan pendapat Rivai dan Sagala (2013:42) yang menyatakan bahwa gaya kepemimpinan adalah sekumpulan ciri yang digunakan pimpinan untuk memengaruhi bawahan agar sasaran organisasi tercapai atau dapat pula dikatakan bahwa gaya kepemimpinan adalah pola perilaku dan strategi yang disukai dan sering diterapkan oleh seorang pemimpin.

Menurut Badeni (2013:2), kepemimpinan dapat diartikan sebagai kemampuan seseorang untuk memberikan influence atau pengaruh kepada suatu kelompok demi terwujudnya tujuan yang telah ditetapkan. Robbins dan Judge (2015:410) menyatakan bahwa kepemimpinan adalah kemampuan memengaruhi suatu kelompok menuju pencapaian sebuah visi atau serangkaian tujuan.

Kreitner dan Kinicki (2010:467) mendefinisikan kepemimpinan sebagai proses di mana seorang individu memengaruhi orang lain untuk mencapai tujuan bersama. McShane dan Von Glinow (2010: 360) menyatakan kepemimpinan adalah tentang memengaruhi, memotivasi, dan memungkinkan orang lain memberikan kontribusi ke arah efektivitas dan keberhasilan organisasi di mana mereka menjadi anggotanya. Kepemimpinan adalah proses memengaruhi dan mendukung orang lain untuk bekerja secara antusias menuju pada pencapaian sasaran. Indikator kepemimpinan demokratis menurut Sudarwan Danim (2012) antara lain: 1) Tanggungjawab bersama, 2) Memiliki kepercayaan, dan 3) Komunikasi terbuka. 
Motivasi dapat didefinisikan sebagai keadaan dimana usaha dan kemauan keras seseorang diarahkan kepada pencapaian hasil-hasil atau tujuan tertentu. Hasil-hasil yang dimaksud bisa berupa produktifitas, kehadiran atau perilaku kerja kreatif lainnya (Wayan, 2012:170). Menurut Robbins dan Judge (2013), "Motivasi adalah proses yang menjelaskan intensitas, arah dan ketekunan seseorang individu untuk mencapai tujuannya".

Dalam suatu lembaga pendidikan, motivasi dosen untuk meningkatkan kinerja merupakan hal yang sangat penting dalam rangkan meningkatkan kualitas pendidikan. Karena motivasi inilah yang mendorong kearah pencapaian prestasi. Seseorang akan melakukan usaha yang maksimal karena dirorong oleh motivasi yang tinggi yang pada akhirnya akan menunjukkan hasil yang maksimal pula.

Teori Herzberg tentang motivasi yaitu terdapat dua faktor yang mempengaruhi motivasi kerja anatara lain faktor internal dan faktor eksternal (Herzberg dalam Hasibuan, 2012:157) yaitu: 1) Faktor intrinsik yang berkaitan dengan isi pekerjaan: (a) Tanggung jawab adalah besarnya tanggung jawab yang dirasakan dan ditanggung oleh pegawai. (b) Promosi tidak mungkin karena pegawai memiliki kemampuan untuk mempromosikan pekerjaan mereka. (c) Pekerjaan itu sendiri, besarnya tantangan yang dirasakan pegawai dari pekerjaan mereka. Achievement (prestasi) mengacu pada kemungkinan pegawai memperoleh hasil kerja dan mencapai kinerja tinggi. (d) Pengakuan mengacu pada tingkat pemberian penghargaan yang diberikan kepada pegawai untuk mencapai kinerja. 2) Faktor eksternal yang menyebabkan ketidakpuasan dan berhubungan dengan lingkungan kerja, antara lain: (a) kebijakan organisasi dan manajemen administrasi (kebijakan organisasi dan manajemen administrasi), dan sejauh mana pegawai mematuhi semua kebijakan dan peraturan yang berlaku dalam organisasi. (b) Kondisi kerja, kondisi kerja dan kesesuaiannya untuk melaksanakan tugas. (c) Gaji dan Upah, kewajaran gaji yang diterima sebagai kompensasi kinerja. (d) Hubungan interpersonal, yaitu derajat kesesuaian yang dirasakan melalui interaksi dengan pegawai lain

Motivasi kerja seseorang tentunya mempunyai tolok ukur atau indikator. Indikator motivasi kerja menurut Herzberg (dalam Winardi, 2013), "bahwa motivasi kerja bukanlah dimensi tunggal, tetapi tersusun dalam dua faktor, yaitu: faktor motivator (satisfier) dan faktor hygiene". Faktor motivator adalah faktor yang menyebabkan terjadinya kepuasan kerja. Sedangakan faktor hygiene berupa kebijakan administrasi, supervisi, hubungan dengan teman kerja, honorariumi, kenyamanan dalam bekerja, kondisi kerja dan status.

Seorang pemimpin harus memiliki kemampuan untuk mempengaruhi orang lain dalam hal ini adalah bawahannya agar bisa bekerjasama melaksanakan programprogram atau kegiatan-kegiatan yang telah ditetapkan secara bersama-sama dalam rangka membangun sebuah organisasi yang sehat. Karena keberadaan jiwa kepemimpinan dari seorang pemimpin organisasi atau lewmbaga pendidikan merupaka sesuatu yang dicita-citakan. Demikian halnya, seorang pemimpin harus mampu membangun komunikasi yang efektif, menghargai serta memberikan kebebasan berpendapat kepada bawahannya. Jika kondisi ini bisa berjalan sebagaimana mestinya maka akan sangat memepengaruhi loyalitas, kinerja serta motivasi bawahan. Keberadaan dosen akan menjadi salah satu factor penentu terwujudnya kualitas mutu pendidikan. Oleh karena itu, setiap dosen harus terus menugapayakan peningkatan kapasitasnya, memiliki berbagai kompetensi serta melaknsanakan amanah serta 
kewajibannya dengan baik dan penuh tanggung jawab. Dan yang paling penting dan tidak boleh terabaikan adalah seorang dosen tidak hanya sekedar mentransfer ilmu pengetahuan akan tetapi juga harus memiliki komitmen yang tinnggi, keikhlasan dalam bekerja serta mampu menjadi teladan yang baik bagi mahasiswanyaa.

Dosen sebagai pendidik di lembaga pendidikan memeiliki peran dan tanggung jawab untuk membangun kesadaran serta kepercayaan diri peserta didiknya bahwa setiap individu memiliki kemampuan dan kompetensi dalam bidang-bidang tertentu sehingga mampu mengembangkan potensi yang ada pada diri masing-masing individu.

Menurut Moeheriono (2012:95), yang mengatakan bahwa kinerja adalah gambaran sejauh mana suatu rencana tindakan atau kebijakan telah dicapai dalam mencapai tujuan, sasaran, visi dan misi organisasi. Dalam beberapa dekade terakhir, kecenderungan untuk meningkatkan koordinasi dalam organisasi untuk meningkatkan kinerja telah menjadi tantangan utama bagi para pemimpin untuk memotivasi pengikut sekaligus meningkatkan kinerja tim dan menjaga keseimbangan di antara mereka. Sejalan dengan pandangan para ahli lainnya, kinerja adalah jumlah upaya yang dilakukan seseorang dalam pekerjaan (Robbins, 2015). Bernardin (2010) percaya bahwa berhasil tidaknya kinerja organisasi bergantung pada tingkat kinerja individu pegawai dan kelompok, dan berasumsi bahwa semakin baik kinerja pegawai maka diharapkan kinerja organisasi semakin baik.

Dalam sebuah hadis, Rasulullah SAW bersabda bahwa: "Tidaklah seorang pemimpin yang diamanati Allah untuk memimpin rakyatnya, lalu dia tidak menjaganya dengan sungguh-sungguh lalu dia mati dalam keadaan mengkhianati rakyatmya, melainkan dia tidak akan mendapatkan aroma surga." Hadis ini memberikan penjelasan bahwa setiap pemimpin agar bertanggung jawab dan siap menannggung risiko serta bersedia mencurahkan pemikiran dan tenaganya untuk kebaikan dan kesejahteraan orang-orang yang dipimpinnya. Seorang dosen harus bertanggung jawab penuh untuk memberikan kemashlahatan kepada mahasiswanya. Rektor atau ketua di perguruan tinggi adalah pemimpin atas orang-orang yang menjadi bawahannya. Tenaga administrasi atau pegawai lainnya adalah pemimpin atas tugas yang telah diamanahkan kepadanya. Dosen adalah pemimpin atas mahasiswanya. Mahasiswa adalah pemimpin atas proses pendidikan yang dilakoninya. Setiap orang yang ada di lembaga pendidikan adalah pemimpin yang akan bertanggung jawab atas kepemimpinannya.

Untuk melihat ketercapaian standar kinerja seorang pegawai dalam hal ini adalah dosen di Perguruan tinggi, maka berkaitan dengan hal tersebut, terdapat lima standar untuk mengukur kinerja individu pegawai (Robbins, 2015: 260), yaitu: 1) Berkualitas atau tidaknya pekerjaan tergantung pada anggapan pegawai terhadap keunggulan hasil dari pekerjaan yang telah dilaksanakan dan tingkat optimalisasi pekerjaan dari skill serta kompetensi pegawai. 2) Kuantitas ditentukan menurut anggapan pegawai tentang banyaknya kegiatan yang ditugaskan dan hasil yang dicapai. Akurasi waktu ditentukan oleh anggapan pegawai terhadap suatu kegiatan yang diselesaikan di tepat waktu hingga menjadi output. 3) Memaksimalkan efisiensi pemanfaatan sumber daya manusia, uang, teknologi, bahan baku untuk meningkatkan hasil setiap unit dalam penggunaan sumber daya, pegawai dalam evaluasi efisiensi penggunaan waktu untuk melakukan tugas, yaitu menyelesaikan tugas yang diberikan kepada efektivitas organisasi. 4) Kemandirian adalah tingkat kompetensi setiap individu untuk menjalankan tugas pekerjaannya dengan tidak mengharapakan pertolongan atau guidance dari orang lain. 5) Komitmen 
kerja adalah tingkat di mana pegawai memiliki komitmen kerja kepada agensi dan bertanggung jawab terhadap organisasi.

Dari penjelasan di atas terdapat fenomena yang terjadi di lapangan khususnya di STAI Ibnu Sina Batam Kepulauan Riau yaitu masih rendahnya kualitas dosen yang disebabkan oleh kurangnya motivasi kerja dosen yang berimbas pada kinerja dosen dalam bidang akademik khususnya dalam melakukan penelitian-penelitian ilmiah serta pengabdian dimasyarakat dan masalah pendampingan mahasiswa dalam kegiatan berorganisasi. Hal yang kedua adalah gaya kepemimpinan yang diterapkan masih perlu ditingkatkan terutama dalam hal pengambilan kebijakan secara demokratis mengenai program - program strategis yang ada di STAI Ibnu Sina Batam Kepulauan Riau.

Berdasar pada uraian diatas maka penelitian ini disusun melalui konsep kerangka konseptual yang dapat digambarkan sebagai berikut :

\section{Kepemimpinan Demokratis}

$\left(\mathbf{X}_{1}\right)$

1. Tanggungjawab bersama

2. Memiliki kepercayaan

3. Komunikasi terbuka

Sudarwan Danim (2012)

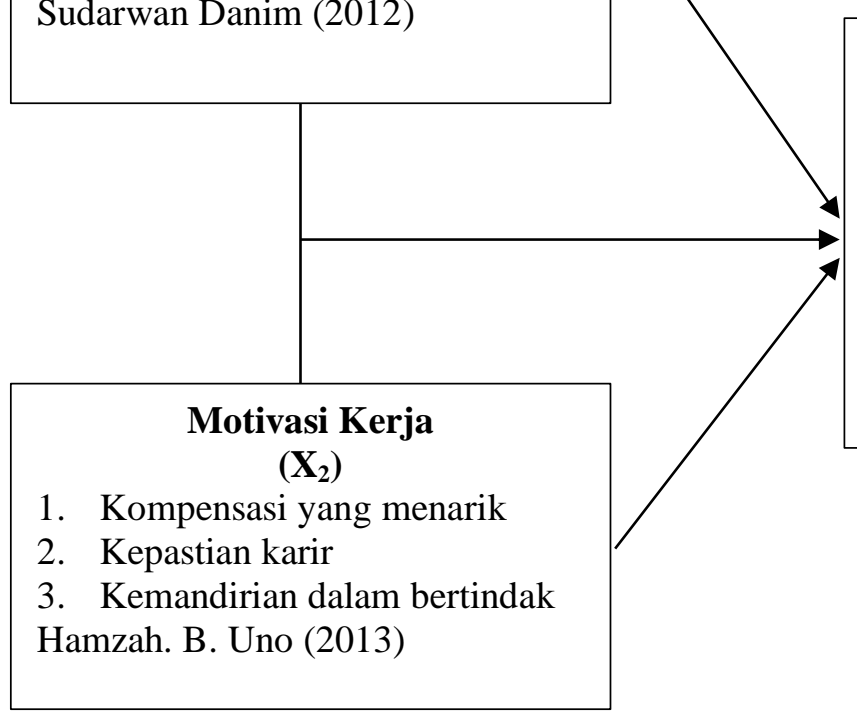

\section{Kinerja Dosen}

(Y)

1. Memenuhi standar kualitas

2. Ketepatan waktu penyelesaian pekerjaan

3. Inisiatif mencari solusi baru

4. Mampu memenuhi target pekerjaan

Uno \& Lamatenggo (2012)

\section{Gambar 1. Kerangka Konseptual}

Melalui gambar kerangka konsep di atas maka akan terdapat hipotesis yang dikembangkan dalam penelitian ini yaitu:

1. Terdapat pengaruh positif dan signifikan kepemimpinan demokratis terhadap kinerja dosen di STAI Ibnu Sina Batam Kepulauan Riau.

2. Terdapat pengaruh positif dan signifikan motivasi kerja terhadap kinerja dosen di STAI Ibnu Sina Batam Kepulauan Riau.

3. Terdapat pengaruh positif dan signifikan kepemimpinan demokratis dan motivasi kerja terhadap kinerja dosen di STAI Ibnu Sina Batam Kepulauan Riau.

\section{METODE PENELITIAN}

Metode penelitian yang digunakan adalah kuantitatif. Metode penelitian kuantitatif dapat diartikan sebagai metode penelitian yang didasarkan pada filosofi 
positivis yang digunakan untuk menguji populasi dan sampel tertentu. Lokasi penelitian ini berada pada STAI Ibnu Sina Batam Kepulauan Riau. Teknik pengambilan sampel biasanya dilakukan secara acak, pengumpulan data menggunakan alat penelitian, dan analisis data bersifat kuantitatif untuk menguji hipotesis yang telah ditentukan. (Sugiyono, 2016:14). Teknik pengumpulan data dilakukan antara lain: 1) menggunakan lembaran observasi yang digunakan peneliti untuk mendapatkan gambaran dan kondisi responden penelitian dengan cara mengamati dan mencatat segala kejadian yang telah dilakukan responden dalam lembaran observasi yang berkaitan dengan kepemimpinan demokratis, motivasi kerja serta kinerja dosen, 2) sejumlah pertanyaan dan pernyataan dalam bentuk kuesioner baik yang bersifat positif maupun negatif dengan menggunakan skala Likert yang berkaitan dengan kepemimpinan demokratis, motivasi kerja serta kinerja dosen, lalu dikumpulkan kembali untuk pengolahan data selanjutnya. 3) kajian dokumentasi yang meliputi data profil STAI Ibnu Sina, karakteristik dosen dan data lainnya yang berkaitan dengan kepemimpinan demokratis, motivasi kerja serta kinerja dosen. Adapun populasi jumlah dosen sebanyak 31 orang, sehingga digunakan teknik pengambilan sampel menggunakan metode sensus dimana seluruh populasi bertindak sebagai sampel sehingga diperoleh sampel sebanyak 31 orang dosen. Teknik analisis data yang digunakan yaitu analisis regresi linier berganda yang didahului dengan uji validitas dan uji reliabiitas terhadap data penelitian. Uji hipotesis digunakan uji $t$ untuk menguji hubungan seara parsial (sendiri-sendiri) dan uji f untuk mengetahui hubungan secara simultan (bersama-sama). Analisis kebermaknaan dalam penelitian ini digunakan melalui uji koefisien determinasi ( $\mathrm{R}$ square). Persamaan analisis regresi digunakan untuk mengetahui adanya pengaruh masing-masing variabel terikat terhadap variabel bebas. Adapun variabel bebas terdiri atas (1) kepemimpinan demokratis, (2) motivasi kerja sedangkan variabel terikat yaitu kinerja dosen. Melalui program SPSS versi 25 dapat diketahui hasil perhitungan analisis regeresi linier berganda tersebut. Rumus regresi linier berganda, yaitu:

$$
\mathrm{Y}=\alpha+\beta_{1} \mathrm{X}_{1}+\beta_{2} \mathrm{X}_{2}+\mathrm{e}
$$

Keterangan:

$\mathrm{Y}=$ Kinerja Dosen

$\mathrm{X}_{1}=$ Kepemimpinan Demokratis

$\mathrm{X}_{2}=$ Motivasi Kerja

$\alpha=$ Konstanta.

$\beta 1=$ Koefisien kepemimpinan demokratis

$\beta 2=$ Koefisien estimate motivasi kerja

$\mathrm{e}=$ variabel pengganggu

\section{HASIL PENELITIAN DAN PEMBAHASAN \\ Hasil Penelitian}

Berdasarkan hasil olah data menggunakan SPSS versi 25 diperoleh nilai coefisien konstanta sebesar -3,032, koefisien kepemimpinan demokratis 1,046, koefisien motivasi kerja 0,038, maka persamaan regresi dapat dirumuskan sebagai berikut:

Tabel 1.

\section{Coefficients $^{\mathrm{a}}$}




\begin{tabular}{|c|c|c|c|c|c|c|c|c|}
\hline \multirow{2}{*}{\multicolumn{2}{|c|}{ Model }} & \multicolumn{2}{|c|}{$\begin{array}{l}\text { Unstandardized } \\
\text { Coefficients }\end{array}$} & \multirow{2}{*}{$\begin{array}{c}\text { Standardized } \\
\text { Coefficients } \\
\text { Beta }\end{array}$} & \multirow[b]{2}{*}{$t$} & \multirow[b]{2}{*}{ Sig. } & \multicolumn{2}{|c|}{ Collinearity Statistics } \\
\hline & & $\mathrm{B}$ & Std. Error & & & & Tolerance & VIF \\
\hline \multirow{2}{*}{$\overline{1}$} & $\begin{array}{l}\text { KEPEMIMPINAN_DEM } \\
\text { OKRATIS }\end{array}$ & 1.046 & .266 & .671 & 3.936 & .000 & .640 & 1.561 \\
\hline & MOTIVASI_KERJA & .038 & .193 & .033 & .195 & .847 & .640 & 1.561 \\
\hline
\end{tabular}

Dari tabel di atas diperoleh persamaan regresi $Y=-3,032+1,046 X_{1}+0,038 X_{2}+e$ berikut:

Berdasarkan hasi uji analisis regresi linear berganda diperoleh hasil sebagai

a. Uji t dilakukan untuk melihat ada tidaknya pengaruh variabel-variabel bebas (kepemimpinan demokratis dan motivasi kerja) terhadap variabel terikat (kinerja dosen) secara parsial. Untuk membuktikan ada tidaknya pengaruh maka akan dilakukan langkah-langkah sebagai berikut:

$\mathrm{H}_{0} \quad$ : kepemimpinan demokratis dan motivasi kerja secara parsial tidak berpengaruh terhadap kinerja dosen

$\mathrm{H}_{1} \quad$ : kepemimpinan demokratis dan motivasi kerja secara parsial berpengaruh terhadap kinerja dosen

1. Berdasarkan tabel uji $t$ diketahui bahwa nilai $t_{\text {hitung }}$ variabel kepemimpinan demokratis $\left(\mathrm{X}_{1}\right)$ sebesar 3,936 lebih dari 1,99 ( $\left.\mathrm{t}_{\text {hitung }}>\mathrm{t}_{\text {tabel }}\right)$ maka $\mathrm{H}_{0}$ ditolak dan $\mathrm{H}_{1}$ diterima, artinya kepemimpinan demokratis secara parsial berpengaruh terhadap kinerja dosen.

\section{Tabel 2}

\begin{tabular}{|c|c|c|c|c|c|c|c|c|}
\hline \multicolumn{9}{|c|}{$\begin{array}{l}\text { Hasil Uji t } \\
\text { Coefficients }^{a}\end{array}$} \\
\hline \multirow{2}{*}{\multicolumn{2}{|c|}{ Model }} & \multicolumn{2}{|c|}{$\begin{array}{l}\text { Unstandardized } \\
\text { Coefficients }\end{array}$} & \multirow{2}{*}{$\begin{array}{l}\text { Standardized } \\
\text { Coefficients } \\
\text { Beta }\end{array}$} & \multirow[b]{2}{*}{$\mathrm{t}$} & \multirow[b]{2}{*}{ Sig. } & \multirow{2}{*}{$\begin{array}{l}\text { Collinearity } \\
\text { Tolerance }\end{array}$} & \multirow{2}{*}{$\begin{array}{c}\text { Statistics } \\
\text { VIF }\end{array}$} \\
\hline & & $B$ & Std. Error & & & & & \\
\hline 1 & (Constant) & -3.032 & 10.866 & & -.279 & .782 & & \\
\hline & $\begin{array}{l}\text { KEPEMIMPINAN_DEM } \\
\text { OKRATIS }\end{array}$ & 1.046 & .266 & .671 & 3.936 & .000 & .640 & 1.561 \\
\hline & MOTIVASI_KERJA & .038 & .193 & .033 & .195 & 847 & .640 & 1.561 \\
\hline
\end{tabular}

2. Berdasarkan tabel diketahui bahwa nilai $t_{\text {hitung }}$ variabel motivasi kerja $\left(\mathrm{X}_{2}\right)$ sebesar 0,195 kurang dari 1,99 ( $\left.\mathrm{t}_{\text {hitung }}>\mathrm{t}_{\text {tabel }}\right)$ maka $\mathrm{H}_{0}$ diterima dan $\mathrm{H}_{1}$ ditolak, artinya motivasi kerja secara parsial tidak berpengaruh terhadap kinerja dosen.

b. Uji $\mathrm{F}$ dilakukan untuk melihat ada tidaknya pengaruh variabel-variabel bebas (kepemimpinan demokratis dan motivasi kerja) terhadap variabel terikat (kinerja dosen) secara bersama-sama. Untuk membuktikan ada tidaknya pengaruh maka akan dilakukan langkah-langkah sebagai berikut:

$\mathrm{H}_{0} \quad$ : kepemimpinan demokratis dan motivasi kerja secara bersama - sama tidak berpengaruh terhadap kinerja dosen.

$\mathrm{H}_{1} \quad$ : kepemimpinan demokratis dan motivasi kerja secara bersama - sama berpengaruh terhadap kinerja dosen. 
3. Berdasarkan hasil uji $\mathrm{F}$ diperoleh nilai $\mathrm{F}_{\text {hitung }}$ sebesar 12,841 dan jika dibandingkan dengan nilai $\mathrm{F}_{\text {tabel }}$ dengan taraf signifikansi $(\alpha)=5 \%$, maka nilai $\mathrm{F}_{\text {tabel }}=2,73$, (artinya $F_{\text {hitung }}>F_{\text {tabel }}(12,841>2,73)$ sehingga dapat dikatakan bahwa $\mathrm{H}_{0}$ ditolak dan $\mathrm{H}_{1}$ diterima, dengan kata lain kepemimpinan demokratis dan motivasi kerja secara bersama-sama berpengaruh terhadap kinerja dosen.

Tabel 3.

\section{Hasil Uji F}

ANOVA $^{\mathrm{a}}$

\begin{tabular}{ll|r|r|r|r|r} 
Model & & Sum of Squares & df & Mean Square & F & Sig. \\
\hline 1 & Regression & 287.575 & 2 & 143.788 & 12.841 & $.000^{\circ}$ \\
\cline { 2 - 7 } & Residual & 313.522 & 28 & 11.197 & & \\
\cline { 2 - 7 } & Total & 601.097 & 30 & & & \\
\hline
\end{tabular}

a. Dependent Variable: KINERJA_DOSEN

b. Predictors: (Constant), MOTIVĀSI_KERJA, KEPEMIMPINAN_DEMOKRATIS

4. Koefisien determinasi $\left(\mathrm{R}^{2}\right)$ dari hasil regresi berganda menujukkan seberapa besar variabel dependen (kinerja dosen) dipengaruhi oleh variabel independen (kepemimpinan demokratis dan motivasi kerja). Hasil uji koefisien determinasi $\left(\mathrm{R}^{2}\right)$ dapat dilihat pada tabel berikut:

\section{Tabel 4.}

\section{Hasil Uji Koefisien Determinasi $\left(\mathbf{R}^{2}\right)$ Model Summary ${ }^{\mathrm{b}}$}

\begin{tabular}{|c|c|c|c|c|c|}
\hline \multicolumn{6}{|c|}{ iviuder suminaly } \\
\hline Model & $\mathrm{R}$ & R Square & $\begin{array}{c}\text { Adjusted R } \\
\text { Square } \\
\end{array}$ & $\begin{array}{c}\text { Std. Error of the } \\
\text { Estimate }\end{array}$ & Durbin-Watson \\
\hline 1 & $.692^{\mathrm{a}}$ & .478 & .441 & 3.34622 & 1.725 \\
\hline
\end{tabular}

a. Predictors: (Constant), MOTIVASI_KERJA, KEPEMIMPINAN_DEMOKRATIS

b. Dependent Variable: KINERJA_DOSEN

Dari data di atas diperoleh koefisien determinasi $\left(\mathrm{R}^{2}\right)$ sebesar 0,478 atau $(47,8 \%)$. Hal ini menunjukkan bahwa 47,8\% kinerja dosen dipengaruhi oleh kepemimpinan demokratis dan motivasi kerja. Sedangkan $52,2 \%$ dipengaruhi oleh variabel lain yang tidak dimasukkan dalam model penelitian ini.

\section{Pembahasan}

Dalam bagian ini akan dibahas pengaruh beberapa faktor yang mempengaruhi kinerja dosen. Pembahasan masing-masing variabel tersebut dikemukakan berikut ini.

\section{Pengaruh secara parsial kepemimpinan demokratis terhadap kinerja dosen.}

Pengaruh kepemimpinan demokratis terhadap kinerja dosen diperoleh nilai $t$ hitung 3,936 dengan signifikansi 0,000 yang berarti bahwa variabel kepemimpinan demokratis mempunyai pengaruh positif dan signifikan terhadap kinerja dosen (Y). Dengan demikian dapat disimpulkan bahwa Ho ditolak dan $\mathrm{H} 1$ diterima, sehingga hipotesis yang menyatakan dugaan adanya pengaruh positif dan signifikan antara kepemimpinan demokratis terhadap kinerja dosen di STAI Ibnu Sina Batam Kepulauan Riau dapat diterima. Kepemimpinan demokratis sangatlah diperlukan dalam rangka 
menciptakan kinerja dosen yang maksimal, mengingat bahwa tugas seorang pimpinan di perdosenan tinggi adalah bagaimana mengatur, mengolah, membimbing sekaligus mengarahkan bawahannya untuk bekerja sesuai dengan pembagian tugas yang telah diberikan sebelumnya. Sehingga dalam melakukan tugas dan fungsinya seorang pimpinan kampus harus senantiasa memperhatikan indikator - indikator yang membuat kinerja dosen semakin meningkat.

\section{Pengaruh secara parsial motivasi kerja terhadap kinerja dosen.}

Pengaruh motivasi kerja terhadap kinerja dosen diperoleh t hitung 0,195 dengan signifikansi 0,847 menandakan bahwa variabel motivasi kerja tidak mempunyai pengaruh positif dan signifikan terhadap kinerja dosen (Y). Dengan demikian dapat disimpulkan bahwa Ho diterima dan H1 ditolak, sehingga hipotesis yang menyatakan dugaan adanya pengaruh positif dan signifikan antara motivasi kerja terhadap kinerja dosen di STAI Ibnu Sina Batam Kepulauan Riau ditolak. Motivasi kerja bagi sebagian orang merupakan suatu hal yang mendorong seseorang untuk melakukan kegiatan dalam rangka mencapai visi misi dan tujuan yang diharapkan. Tanpa motivasi kerja yang tinggi, maka mustahil bagi seorang dosen dalam melaksanakan tugas dan tanggungjawab dengan baik, sehingga menjadi hal yang mutlak bagi setiap dosen untuk menjaga agar motivasi kerjanya terus meningkat dan berkesinambungan.

Dari hasil penelitian yang menunjukkan tidak adanya pengaruh motivasi kerja terhadap kinerja dosen menunjukkan bahwa indikator yang terdapat pada variabel motivasi kerja masih perlu mendapat perhatian yang serius bagi stakeholder yang berkepentingan sehingga diharapkan kinerja dosen yang diinginkan dapat tercapai dengan baik.

\section{Pengaruh secara simultan variabel kepemimpinan demokratis dan motivasi kerja terhadap kinerja dosen}

Berdasarkan hasil analisis diperoleh nilai $\mathrm{F}$ sebesar 12,841 dengan nilai signifikansi 0,000 lebih kecil dari 0,05, maka dapat diketahui bahwa secara simultan ada pengaruh signifikan antara kepemimpinan demokratis dan motivasi kerja terhadap kinerja dosen di STAI Ibnu Sina Batam Kepulauan Riau. Demikian pula berdasarkan uji koefisien determinasi diperoleh koefisien determinasi $\left(\mathrm{R}^{2}\right)$ sebesar 0,478 atau (47,8\%). Hal ini menunjukkan bahwa 47,8\% kinerja dosen dipengaruhi oleh Kepemimpinan demokratis dan motivasi kerja. Sedangkan 52,2\% dipengaruhi oleh variabel lain yang tidak dimasukkan dalam model penelitian ini.

\section{SIMPULAN}

Berdasarkan hasil penelitian dan pembahasan yang telah dikemukakan di atas dapat ditarik beberapa kesimpulan sebagai berikut :

1. Secara parsial kepemimpinan demokratis ( sig $0,029<\alpha 0,05)$ berpengaruh secara positif dan signifikan terhadap kinerja dosen di STAI Ibnu Sina Batam Kepulauan Riau. Ini berarti bahwa kepemimpinan demokratis harus terus ditingkatkan dalam rangka menciptakan dosen yang professional.

2. Secara parsial motivasi kerja (Sig $0,847>\alpha 0,05$ ) tidak mempunyai pengaruh positif dan signifikan terhadap kinerja dosen di STAI Ibnu Sina Batam Kepulauan Riau. Ini berarti bahwa motivasi kerja dosen harus senantiasa ditingkatkan untuk memaksimalkan kinerja seorang dosen. 
3. Secara simultan menunjukkan bahwa kepemimpinan demokratis $\left(\mathrm{X}_{1}\right)$ dan motivasi kerja $\left(\mathrm{X}_{2}\right)$ berpengaruh secara positif dan signifikan terhadap kinerja dosen di STAI Ibnu Sina Batam Kepulauan Riau (Y). Hal ini berarti bahwa peningkatan kepemimpinan demokratis dan motivasi kerja mempengaruhi kinerja dosen sebesar 47,8\% Sedangkan 52,2\% dipengaruhi oleh variabel lain yang tidak dimasukkan dalam model penelitian ini.

\section{SARAN}

Berdasarkan simpulan dari hasil penelitian di atas, maka adapun saran yang dapat direkomendasikan adalah:

1. Pihak pimpinan STAI Ibnu Sina Batam Kepulauan Riau agar senantiasa menerapkan gaya kepemimpinan yang demokratis kepada dosen dan segenap civitas akademik dalam rangka menciptakan kinerja dosen yang maksimal guna mencapai visi, misi dan tujuan perdosenan tinggi.

2. Pihak pimpinan STAI Ibnu Sina Batam Kepulauan Riau agar memberikan motivasi kepada dosen dalam bentuk pemberian kompensasi yang menarik yang bisa berupa bantuan beasiswa untuk memberikan semangat bagi dosen dalam melanjutkan pendidikan demia karir yang lebih baik.

3. Perlu penelitian lanjutan yang melibatkan variabel lain yang dapat mempengaruhi kinerja dosen di STAI Ibnu Sina Batam Kepulauan Riau.

\section{DAFTAR PUSTAKA}

Badeni. 2013. Kepemimpinan dan Perilaku Organisasi. Bandung: Alfabeta.

Bachtiar, D. 2013. Pengaruh Motivasi dan Lingkungan Kerja Terhadap Kinerja Pegawai. $\quad$ Management Analysis Journal 1 (1), 1-6.

Bernadin. Human resource management, jurnal Reza, Aditya, Regina, 2010. Pengaruh gaya kepemimpinan, motivasi dan disiplin kerja terhadap kinerja pegawai pada PT. Sinar Sentosa Perkasa Banjarnegara

Ghozali, I. 2018, Aplikasi Multivariate, Dengan Program IBM SPSS 25. Semarang. BP. UNDIP.

Hamzah B Uno dan Nana Lamatenggo. 2014. Teori Kinerja dan Pengukurannya, Jakarta : PT. Bumi Aksara

Hasibuan, Malayu S.P. 2012. Manajemen Sumber Daya Manusia. Jakarta: PT Bumi Askara.

Kreitner, Kinicki. 2010. Organizational Behavior. New York: McGraw-Hill.

McShane, S. L., \& Von Glinow, M. A. 2010. Organizational Behavior:Emerging Knowledge and Practice for The Real World (5th ed.). New York: The McGraw-Hill Companies, Inc. 
Miao, et.al. 2010. Perceived Organizational Support, Job Satisfaction and Employee Performance: An Chinese Empirical Study. Journal of Service Science and Management, 3(2) pp:257-264

Moeheriono, 2012. Pengukuran Kinerja Berbasis Kompetensi. Jakarta: Raja Grafindo Persada

Miftah Thoha. 2013. Kepemimpinan dalam manajemen. Jakarta : Raja Grafindo Persada

Rivai Dan Ella Sagala, 2013. Manajemen Sumber Daya Manusia Untuk Perusahaan, Rajawali Pers, Jakarta

Robbins, Stephen P \& Judge, Timothy A. 2013. Organizational Behavior Edition. 15. New Jersey: Pearson Education

Robbins, Stephen. 2015. Organizatioal Behavior. $9^{\text {th }}$. Edition. New Jersey Precentice Hall International Inc

Robbin \& Judge. 2015. Perilaku Organisasi Edisi 16. Jakarta. Salemba Empat.

Sudarwan Danim. 2012. Motivasi Kepemimpinan dan Efektivitas Kelompok. Jakarta: Rineka Cipta

Sugiyono. 2016. Metode Penelitian Pendidikan. Bandung: Alfabeta Bandung

Wayan I Ardana dkk. 2012. Manajemen Sumber Daya Manusia. Yogyakarta: Graha Ilmu

Wibowo. 2011. Manajemen Kinerja. Jakarta: Raja Grafindo Persada.

Winardi, J. 2013. Motivasi Pemotivasian. Jakarta: Rajawali Press.

Zazin Nur, 2011. Gerakan Menata Mutu Pendidikan. Teori dan Aplikasi. Jakarta: ArRuzz Media 